\title{
Energy-dense diets are associated with lower diet costs: a community study of French adults
}

\author{
Nicole Darmon ${ }^{1}$, André Briend ${ }^{2}$ and Adam Drewnowski ${ }^{3,4, *}$ \\ 'Unité INSERM 557, Conservatoire National des Arts et Métiers, ISTNA, 2 rue Conté, F-75003 Paris, France: \\ ${ }^{2}$ Institut de Recherche pour le Développement, F-75010 Paris, France: ${ }^{3}$ Nutritional Sciences Program, School of Public \\ Health and Community Medicine, University of Washington, Seattle, WA 981 15, USA: ${ }^{4}$ Correspondence address: \\ 305 Raitt Hall, Box 353410, University of Washington, Seattle, WA 98195, USA
}

Submitted 3 March 2003: Accepted 25 June 2003

\begin{abstract}
Objective: High consumption of energy-dense foods has been linked to high energy intakes and excess weight gain. This study tested the hypothesis that high energy density of the total diet is associated with lower diet costs.

Design: Dietary intakes of 837 French adults, aged 18-76 years, were assessed using a dietary history method. Dietary energy density $\left(\mathrm{MJ} \mathrm{kg}^{-1}\right)$ was calculated by dividing total energy by the edible weight of foods consumed. Daily diet cost $\left(€\right.$ day $\left.^{-1}\right)$ was estimated using mean national food prices for 57 food items. The relationship between dietary energy density and diet cost at each level of energy intake was examined in a regression model, adjusted for gender and age.

Results: The more energy-dense refined grains, sweets and fats provided energy at a lower cost than did lean meats, vegetables and fruit. Within each quintile of energy intake, diets of lower energy density $\left(\mathrm{MJ} \mathrm{kg}^{-1}\right)$ were associated with higher diet costs $\left(€ \mathrm{day}^{-1}\right)$.

Conclusion: In this observational study, energy-dense diets cost less whereas energydilute diets cost more, adjusting for energy intakes. The finding that energy-dilute diets are associated with higher diet costs has implications for dietary guidelines and current strategies for dietary change.
\end{abstract}

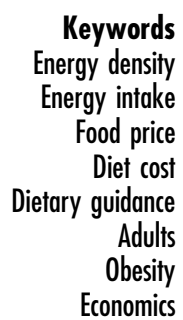

Energy-dense diets have been associated with higher energy intakes and may be related to excess weight gain $^{1-6}$. Energy-dense foods are generally described as those that are high in fat, sugar or $\operatorname{starch}^{7,8}$. In contrast, fruit, vegetables and juices with a high water content are energy-dilute ${ }^{7,9}$. Energy-dense diets are those high in fats, sweets, fast foods and desserts, whereas energydilute diets are those with a high proportion of vegetables and fruit ${ }^{5,6}$. A recent Technical Report from the World Health Organization has linked high consumption of energy-dense foods to the global obesity epidemic ${ }^{7}$.

Dietary strategies for health promotion increasingly call for taxes or levies on energy-dense foods containing added sugars and fats ${ }^{10-12}$. The intent of fiscal and policy interventions is to limit the consumption of fats and sweets or to provide funds to promote alternative and healthier food choices. Reducing dietary energy density through the consumption of vegetables and fruit is one approach to the clinical management of body weight ${ }^{6,13}$. Among suggested strategies for obesity prevention at the population level are restricting the intake of energy-dense foods, promoting vegetable and fruit intakes, and the provision of economic incentives for the production and marketing of healthier food products ${ }^{7}$.

At this time, there are few observational studies relating diet composition to diet costs. We recently found in a group of French adults that freely chosen diets high in fruit and vegetables were associated with higher diet costs ${ }^{14}$. In a study of UK women, Cade et al. ${ }^{15}$ found that diet quality, largely measured by a composite index of fruit and vegetable consumption, was also associated with sharply higher diet costs. An observational study in Denmark has also shown that low-fat diets for children tend to cost more $^{16}$. Computer modelling studies based on linear programming revealed that reducing diet costs led to a major reduction in the vitamin and mineral contents of the predicted diets ${ }^{17}$. However, there is no consensus on this issue. At least two intervention studies in the USA purport to show that nutrient-dense diets are not more expensive than lower-quality diets and may even cost less ${ }^{18,19}$. Likewise, an intervention study in American children showed that low-fat diets for children did not lead to increased food $\operatorname{costs}^{20}$. 
Economic forces may hold the key to dietary change $e^{14,21-23}$. In particular, energy-dense foods, high in added sugars and fat, are popular because they are palatable, convenient, and because they provide dietary energy at a very low cost ${ }^{9}$. Our hypothesis was that dietary energy density and daily diet costs would be inversely linked, after adjusting for energy intakes. In other words, energy-dense diets may be associated with a net saving in diet costs to the consumer. This study therefore examined, for the first time, the relationship between dietary energy density and the estimated costs of freely chosen diets in a community study. Analyses were based on a French dietary dataset ${ }^{24}$, merged with national food prices provided by the French government ${ }^{25}$. Clarifying the relationship between diet quality, energy density and diet costs has implications for dietary guidelines and strategies for dietary change.

\section{Methods}

\section{Survey design and dietary assessment}

The Val-de-Marne dietary survey, conducted in 1988-89, used a two-stage cluster-design sampling procedure. A description of the sampling and interview techniques and other methodological details of the study have been published $^{24,26}$. The study was based on 12 of the 47 districts in the Department of Val-de-Marne that were selected by probability sampling, where the probability of selection was proportional to district size. In the second stage, 75 families per district were selected at random from area telephone directories. Of the 849 families contacted, 527 took part in the study (62\% response rate). The present analyses were based on 837 adults aged $\geqslant 18$ years $(361$ men and 476 women). Trained dietitians interviewed members of each household at home. Dietary intakes were estimated using a dietary history interview, based on daily intakes representative of a habitual diet over 6 months ${ }^{27}$. Habitual food consumption at breakfast, lunch and dinner, and during snacks, was assessed in terms of frequencies (per week) and quantities consumed (i.e. portion sizes) in a manner similar to a food-frequency questionnaire. Each food consumed was assigned a food item and combination foods were desegregated into two or more food items. In particular, the fats used for cooking were counted separately, and added to the other fats consumed. Dietary intake data were then used to calculate daily amounts of 73 distinct foods and food groups, as well as water and five types of alcoholic beverage. The complete Val-de-Marne nutrient database, calculated by INSERM, has been published previously ${ }^{24}$. The ethics committee of CNAM-Paris approved the study protocol.

\section{Energy density}

The present analyses were based on 57 of the 73 food items in the Val-de-Marne database. Drinking water and alcoholic beverages were excluded, as were 10 baby and infant formula products and other foods never consumed by adults. Foods consumed by less than 5\% of the population, including low-fat soft cheese, fats and spreads $(n=6)$, were also excluded. The 57 food items are listed Table 1.

The amounts consumed by each participant, estimated in grams per day, were used to calculate daily energy intakes. The edible portion of each food was taken into account in calculating diet weight. Dietary energy density $\left(\mathrm{MJ} \mathrm{kg}^{-1}\right.$ ) was obtained by dividing energy intake by the estimated edible weight of all foods and caloric beverages consumed (excluding alcohol). As such, the calculation was analogous to method 2 of Cox and Mela ${ }^{1}$ and one of the methods previously used by Gibson ${ }^{28}$. The weight of drinking water and non-caloric beverages is generally excluded from dietary energy density calculations ${ }^{1}$.

\section{Estimated diet costs}

For each of the 57 food items in the database, we selected a single representative example that was the most (or one of the most) frequently consumed items in that particular category. The representative foods tended towards

Table 1 Food items used in the analysis and their energy costs

\begin{tabular}{|c|c|}
\hline Food group & Food item (energy cost, $€ \mathrm{MJ}^{-1}$ ) \\
\hline Meats & $\begin{array}{l}\text { Red meat (1.23), lean meat (2.17), poultry (1.14), liver }(0.73) \text {, organ meats }(0.93) \text {, pork }(2.29) \text {, } \\
\text { lunch meats }(0.39) \text {, eggs }(0.42) \text {, fresh fish }(3.92) \text {, canned fish }(0.98) \text {, shellfish }(3.61)\end{array}$ \\
\hline Fruit \& Vegetables & $\begin{array}{l}\text { Potatoes }(0.30) \text {, root vegetables }(0.92) \text {, peas and beans }(0.79) \text {, pulses }(0.04) \text {, mixed vegetables }(3.18) \text {, leafy } \\
\text { vegetables }(4.89) \text {, tomatoes }(3.84) \text {, fresh fruit }(1.17) \text {, citrus fruit }(1.49) \text {, bananas/raisins/figs }(0.59) \text {, } \\
\text { nuts }(0.09) \text {, dried fruit }(0.41) \text {, canned fruit }(0.38), 100 \% \text { fruit juice }(0.51)\end{array}$ \\
\hline Dairy & $\begin{array}{l}\text { Whole milk }(0.31) \text {, low-fat milk }(0.30) \text {, skimmed milk }(0.34) \text {, yoghurt }(0.78) \text {, fruit yoghurt }(0.35) \text {, pudding }(0.33) \text {, } \\
\text { uncured cheese } 40 \% \text { fat }(0.41) \text {, uncured cheese } 20 \% \text { fat }(0.52) \text {, uncured cheese } 0 \% \text { fat }(0.84) \text {, } \\
\text { hard cheese }(0.50) \text {, soft cheese }(0.48)\end{array}$ \\
\hline Grains & $\begin{array}{l}\text { Bread }(0.26) \text {, whole-grain bread }(0.34) \text {, rolls }(0.15) \text {, breakfast cereals }(0.32) \text {, pasta/rice }(0.13) \text {, } \\
\text { bakery goods }(0.26) \text {, crackers }(0.19) \text {, pastries }(0.38) \text {, cookies }(0.14)\end{array}$ \\
\hline Fats \& Sweets & $\begin{array}{l}\text { Butter }(0.18) \text {, light butter }(0.36) \text {, cream }(0.22) \text {, oil }(0.04) \text {, margarine }(0.09) \text {, sugar }(0.08) \text {, chocolate }(0.30) \text {, } \\
\text { hard candy }(0.33) \text {, syrup }(0.20) \text {, honey/jam }(0.22) \text {, carbonated beverages }(0.48) \text {, cocoa powder }(0.15)\end{array}$ \\
\hline
\end{tabular}


the most available and least expensive, based on expert judgement. We were assisted in this task by the nutritionist who trained the dietitians for the Val-de-Marne survey. Mean national retail prices for year 2000 for each of the 57 items were provided by the French National Institute of Statistics (INSEE) ${ }^{25}$. A column of prices in Euros ( $1 €=$ US\$ 1.17 in June 2003) was then added to the Val-de-Marne food composition database.

The price of red meat was based on the price of frozen hamburgers, whereas the price of poultry was based on chicken breasts. The prices of hard cheese and soft cheese were based on the price of Emmental and Camembert cheeses, respectively. The price of potatoes, root vegetables and tomatoes was based on fresh potatoes, fresh tomatoes and fresh carrots, the price of peas and beans was based on canned peas, the price of pulses was based on dried lentils and the price of mixed vegetables was based on mixed canned vegetables. Using other and more recent surveys of dietary habits in France, we were able to verify a posterior $i$ that the foods selected for pricing were effectively the most frequently or the most heavily consumed. The energy cost (in $€ \mathrm{MJ}^{-1}$ ) of each food item is provided in Table 1 .

\section{Underreporting of energy intakes}

Self-reported dietary intakes are generally found to be 10-30\% below minimum estimates needed for survival, as calculated from the basal metabolic rate (BMR) adjusted for age, gender, height and weight ${ }^{29}$. However, there has not been any evidence of underreporting of macronutrients when they are expressed as a percentage of energy, and nutrient densities did not change appreciably when underreporters were excluded ${ }^{30}$. As a ratio measure, dietary energy density $\left(\mathrm{MJ} \mathrm{kg}^{-1}\right)$ is exactly analogous to nutrient density measures, such as percentage of energy from fat. Using the Goldberg cut-off method recently reevaluated by Black $^{31}$, we computed the energy intake/BMR ratio to be 1.08. Persons with reported ratios of energy intake/BMR $<1.08$ were considered by this technique to be underreporters $(n=183)$. Their exclusion had no impact on dietary energy density values and did not affect the strength of any of the correlations reported below.

\section{Statistical analyses}

The relationship between dietary energy density and daily energy intake was first tested in a univariate regression model for the whole sample, and then for men and women separately. The complex relationships between energy intake, diet weight and diet cost were tested using multivariate regression analysis with diet cost as the dependent variable and energy intake and diet weight as independent variables, adjusting for age and gender. Following the nutrient density analogy, dietary energy density was not entered per se in the regression model. Instead, an interaction term, energy intake by diet weight, was included and considered the operational form of dietary energy density in the multiple regression analysis. As noted above, underreporters were excluded from some analysis to test the robustness of the results. Finally, participants were split by quintiles of energy intake $\left(\mathrm{MJ} \mathrm{day}^{-1}\right.$ ) and the relationship between dietary energy density and diet cost was assessed separately for each quintile in a regression model, adjusted for gender and age. Statview statistical software (Statview version 5; Abacus Concepts, Inc., Berkeley, CA, USA) and SPSS version 9.0 (SPSS Inc., Chicago, IL, USA) were used for analyses.

\section{Results}

Consistent with past observations ${ }^{3}$, dietary energy density $\left(\mathrm{MJ} \mathrm{kg}^{-1}\right)$ was correlated with daily energy intake $\left(\mathrm{MJ} \mathrm{day}^{-1}\right)$ in a univariate regression analysis $\left(R^{2}=0.31\right.$, $P<0.0001)$. Adjustment for age and gender or the exclusion of underreporters did not change the strength of the association $\left(R^{2}=0.31, P<0.0001\right.$ in both cases $)$.

Dietary energy density was positively correlated with percentage of energy from grains and from fats and sweets, and negatively with percentage of energy from fruit and vegetables and from dairy products. A Pearson correlation matrix of dietary energy density with intakes of selected food groups (as \% of energy) is shown in Table 2. Although primarily driven by water, dietary energy density was not independent of the diet's macronutrient content. Pearson correlation coefficients also showed that dietary energy density was positively associated with percentage

Table 2 Pearson correlation matrix of dietary energy density $\left(\mathrm{MJ} \mathrm{kg}^{-1}\right)$ with intakes of five major food groups (expressed as \% of energy)

\begin{tabular}{|c|c|c|c|c|c|}
\hline & $\begin{array}{l}\text { Energy density } \\
\quad\left(\mathrm{MJ} \mathrm{kg}^{-1}\right)\end{array}$ & $\begin{array}{c}\text { Grains } \\
(\%)\end{array}$ & $\begin{array}{c}\text { Fruit \& Vegetables } \\
\qquad(\%)\end{array}$ & $\begin{array}{l}\text { Meat } \\
(\%)\end{array}$ & $\begin{array}{l}\text { Dairy } \\
(\%)\end{array}$ \\
\hline \multicolumn{6}{|l|}{ Energy density ( $\mathrm{MJ} \mathrm{kg}^{-1}$ ) } \\
\hline Grains (\%) & $0.36^{\star \star}$ & & & & \\
\hline Fruit \& Vegetables (\%) & $-0.52^{\star *}$ & $-0.40^{\star *}$ & & & \\
\hline Meat (\%) & $-0.08^{*}$ & $-0.35^{\star \star}$ & 0.00 & & \\
\hline Dairy (\%) & $-0.25^{\star *}$ & $-0.30^{\star *}$ & $-0.13^{\star *}$ & $-0.28^{\star \star}$ & \\
\hline Fats \& Sweets (\%) & $0.30^{\star *}$ & $-0.31^{\star *}$ & $-0.21^{\star \star}$ & $-0.21^{\star \star}$ & $-0.24^{\star \star}$ \\
\hline
\end{tabular}


of energy from sugar $(r=0.23 ; P<0.01)$ and fat $(r=0.42 ; P<0.01)$ and negatively with percentage of energy from protein $(r=-0.50 ; P<0.01)$ and energyadjusted values for fibre $(r=-0.59 ; P<0.01)$ and vitamin $\mathrm{C}(r=-0.59 ; P<0.01)$. Meat, dairy products, vegetables and fruit have higher water contents, and therefore lower energy density, than do fats and sweets.

Multiple regression analyses were then conducted using diet cost as the dependent variable. The interaction term between energy intake and diet weight was negatively associated with diet cost in a model that also contained energy intake, diet weight, age and gender $\left(R^{2}=0.68\right.$, $P<0.0001)$. Exclusion of underreporters did not change the strength of this association $\left(R^{2}=0.70, P<0.0001\right)$. That association suggested an inverse relationship between dietary energy density and diet cost that was analysed further using partial correlations within each quintile of energy intake. Figure 1 shows the univariate relationship between diet cost $\left(€ \mathrm{day}^{-1}\right)$ and energy density $\left(\mathrm{MJ} \mathrm{kg}^{-1}\right)$ within each quintile of energy intake as well as the regression lines. At each level of energy intake, energy-dense diets cost less than energy-dilute diets.
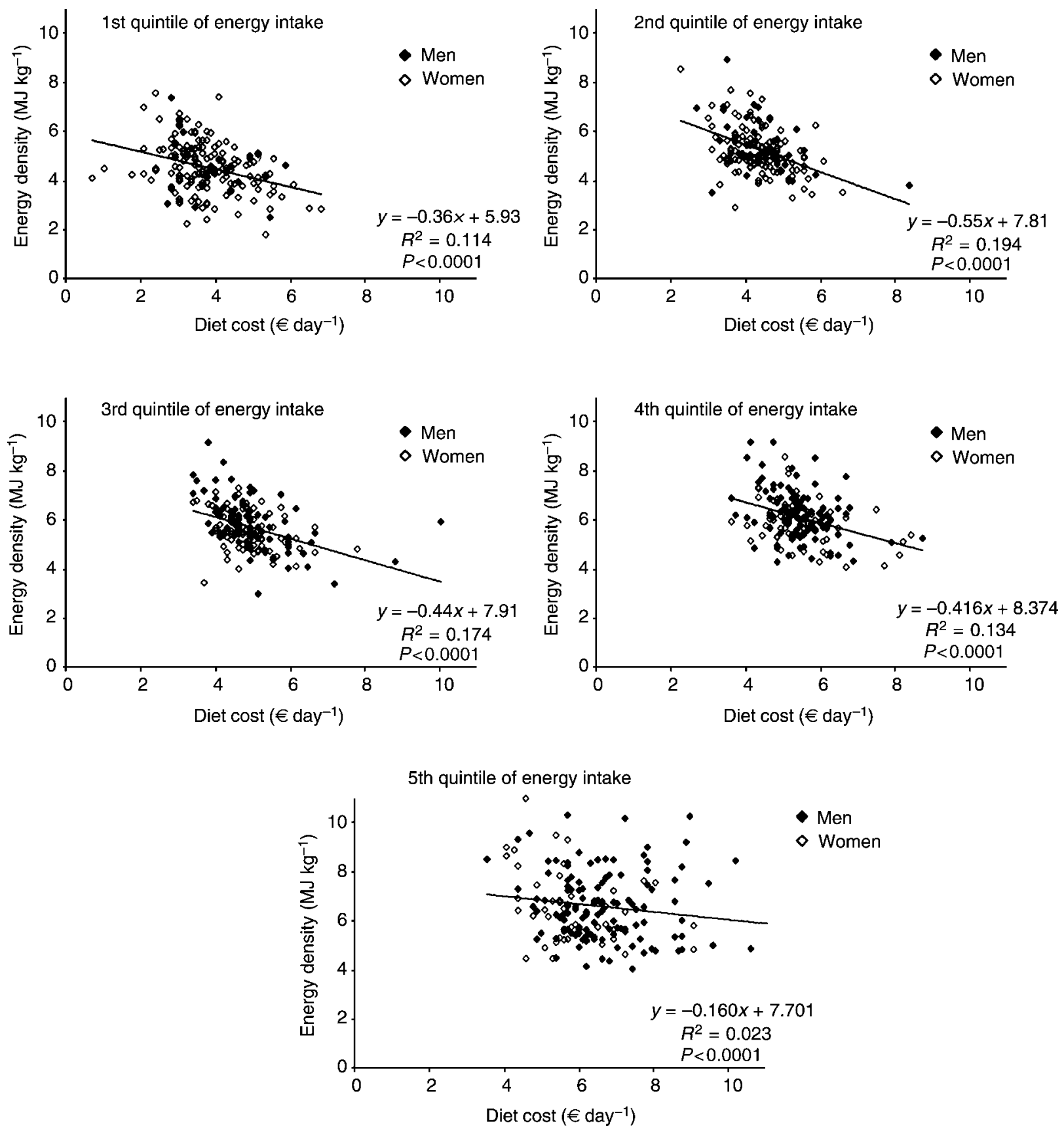

Fig. 1 Relationship between energy density and diet cost, showing regression lines within each quintile of energy intake, for men and women participants in the Val-de-Marne study 
The regression coefficients were significant at each level of intake, although the slope was flatter for the top quintile of energy intake. Adjustment for age and sex further strengthened the association within each energy intake quintile.

\section{Discussion}

The present results confirm past observations that the consumption of energy-dense diets is associated with higher energy intakes ${ }^{1-5}$. The present results also confirm past observations that energy-dense diets tend to be those with a high proportion of fats and sweets, whereas energydilute diets are those with a higher proportion of dairy products, vegetables and fruit ${ }^{5}$.

However, our data also reveal that, at each level of energy intake, higher dietary energy density was associated with lower diet cost. Dietary energy density is largely determined by the water content of foods. Since water contributes the bulk of food weight, it influences energy density of foods more than does any macronutrient ${ }^{2,13,32}$. The costs of transport, storage and waste are higher for perishable fresh produce than for packaged energy-dense foods, which are dry and tend to have a stable shelf life. It is an irrefutable fact that, on a per $\mathrm{kJ}$ basis, energy-dense foods are less costly than energydilute foods. At global market prices, refined sugar and vegetable oils provide as much as $80000 \mathrm{~kJ}$ per dollar ${ }^{33}$. In contrast, the cost per $\mathrm{kJ}$ of energy-dilute fresh produce is higher by several thousand per cent. Likewise, it is clear from the present data that the energy cost of most food items in the fruit and vegetables group (except potatoes, nuts and dried pulses) was much higher than that of fats and sweets (Table 1).

The present study is the first to provide evidence for an inverse relationship between dietary energy density and estimated diet cost. However, there are important limitations. First, in the absence of food expenditure data, the model was based on national retail food prices. In effect, the model estimated what each diet cost, as opposed to what the consumer paid for it. There are several precedents for estimating diet costs using mean prices for purchased food items from area stores ${ }^{18}$. In a UK study, direct monetary cost of the diet was calculated using average national prices from the 1995 National Food Survey and the Tesco home shopping catalogue ${ }^{15}$. In order to estimate the costs of the French diet, we linked dietary intake data from a nutrition survey conducted in Val-de-Marne in $1988^{24}$ with a current list of mean national food prices published by INSEE in $2000^{25}$. The principal reasons for using the Val-de-Marne survey were sample size $(n=837)$, high quality of dietary data obtained through individual interviews with trained dietitians, and our previous experience with the dataset ${ }^{26}$. There was also a good match between the foods included in the nutrient database and the foods included by INSEE in their published list of food prices. The disparity in time between data collection in 1988-89 and the use of 2000 food prices could not be avoided. However, French government agencies report that dietary changes between 1985-1990 and the present day were relatively minor, since the most profound shifts had already occurred between 1950 and $1985^{34}$. Our estimate of a daily diet cost of around $5 €$ day $^{-1}$ was remarkably close to the mean national expenditure for food at home as calculated by INSEE from the National Budget Survey, i.e. $4.9 €$ per person per day ${ }^{35}$. Given that both obesity ${ }^{36-39}$ and type 2 diabetes ${ }^{40,41}$ follow a socio-economic gradient, there is an urgent need for further analyses of the association between diet quality, dietary energy density and diet cost. Future studies should be based on more recent dietary data and a more precise evaluation of diet costs or actual food expenditures. However, since the present model has produced such striking results, it is likely that the inverse association between dietary energy density and energy costs will only be confirmed in further studies.

The observation that energy-dense diets cost less has important policy and political implications. According to Engel's law, the proportion of disposable income spent on food increases as incomes $\operatorname{drop}^{42,43}$. In the general population, consumers select foods on the basis of taste, cost and convenience, and to a lesser extent on health and variety $^{44,45}$. However, among low-income households and the unemployed, cost and taste are the key determinants of food choice ${ }^{44,45}$. Although food prices affect everyone, the issue of food cost as a barrier to dietary change is particularly relevant to low-income families ${ }^{46-48}$. This may explain why the consumption of healthy diets rich in fruit and vegetables is so low among groups with low education and incomes ${ }^{43,49-53}$. The present results support the recently raised hypothesis that the links observed between poverty and obesity in industrialised societies $^{36-39}$ are related to the low cost and high palatability of energy-dense diets ${ }^{33}$.

The present observational studies do not speak directly to the cost of dietary change following nutritional interventions ${ }^{18-20}$. Nutrition education programmes in the USA, aimed at the low-income consumer, include the Expanded Food and Nutrition Education Program (EFNEP) and the Food Stamp Nutrition Education Program $(\text { FSNEP })^{19}$. These programmes provide individual instruction on how to identify low-cost nutritious foods, how and where to make food purchases, and how to store and prepare the foods. However, the recommended diets, while meeting dietary guidelines, may be low on palatability and convenience, being composed of potatoes, rice, beans, pasta, ground turkey and frozen orange juice ${ }^{54}$.

However, there is a dissociation between dietary recommendations and guidelines and the simple economics of the food supply ${ }^{55}$. Energy-dense foods - often containing refined grains, added sugars and fats - are 
palatable, easily accessible, convenient and inexpensive ${ }^{8,9}$. For many low-income consumers they may have become the norm. Insisting that the public consumes more costly diets high in lean meat, whole grains and fresh vegetables and fruits ${ }^{56}$ is economic elitism that can only generate frustration and culpability among the poor and less educated. This may account for the consumer backlash observed among these groups and directed against diet and health messages ${ }^{57}$. There has also been reluctance among lower-income groups to change dietary behaviour in response to a dietary information campaign $^{58}$.

A focus on the economics of food choice is greatly overdue. Studies on the obesity epidemic and the contribution of snacks, fast foods, foods away from home and the phenomenon of supersizing ${ }^{8,59,60}$ have not addressed the very low energy costs of added sugars and fat. Among suggested strategies for reducing the consumption of energy-dense foods are taxes, levies, limits on advertising and outright bans ${ }^{10-12}$. Whether such punitive tactics will steer lower-income consumers toward more costly food choices is an unresolved issue. There is a need for additional studies on diet structure and food costs on which to base responsible nutrition interventions and fiscal food policy.

\section{Acknowledgement}

Supported by INSERM Unit 557, INRA, and by a Fogarty Senior International Fellowship to A.D. (FO6 TW02187).

\section{References}

1 Cox DN, Mela DJ. Determination of energy density of freely selected diets: methodological issues and implications. International Journal of Obesity and Related Metabolic Disorders 2000; 24: 49-54.

2 Stubbs J, Ferres S, Horgan G. Energy density of foods: effects on energy intake. Critical Reviews in Food Science and Nutrition 2000; 40: 481-515.

3 Poppitt SD, Prentice AM. Energy density and its role in the control of food intake: evidence from metabolic and community studies. Appetite 1996; 26: 153-74.

4 Marti-Henneberg C, Capdevila F, Arija V, Perez S, Cuco G, Vizmanos B, et al. Energy density of the diet, food volume and energy intake by age and sex in a healthy population. European Journal of Clinical Nutriton 1999; 53: 421-8.

5 Cuco G, Arija V, Marti-Henneberg C, Fernandez-Ballart J. Food and nutritional profile of high energy density consumers in an adult Mediterranean population. European Journal of Clinical Nutrition 2001; 55: 192-9.

6 Rolls BJ, Bell EA. Dietary approaches to the treatment of obesity. Medical Clinics of North America 2000; 84: 401-18, vi.

7 World Health Organization (WHO), Diet, Nutrition and The Prevention of Excess Weight Gain and Obesity. Report of a Joint WHO/FAO Expert Consultation. WHO Technical Report Series No. 916. Geneva: WHO, April 2003.

8 Kant AK. Consumption of energy-dense, nutrient-poor foods by adult Americans: nutritional and health implications. The Third National Health and Nutrition Examination Survey,
1988-1994. American Journal of Clinical Nutrition 2000; 72: $929-36$.

9 Drewnowski A. The role of energy density. Lipids 2003; 38: 109-15.

10 Jacobson MF, Brownell KD. Small taxes on soft drinks and snack foods to promote health. American Journal of Public Health 2000; 90: 854-7.

11 Nestle M. The politics of food choice. In: Nestle M, ed. Food Politics: How the Food Industry Influences Nutrition and Health, 1st ed. Los Angeles, CA: University of California Press Ltd, 2002; 358-74.

12 Marshall T. Exploring a fiscal food policy: the case of diet and ischaemic heart disease. British Medical Journal 2000; 320: $301-5$.

13 Drewnowski A. Energy density, palatability, and satiety: implications for weight control. Nutrition Reviews 1998; 56: 347-53.

14 Drewnowski A, Darmon N, Briend A. Replacing fats and sweets with vegetables and fruit - a question of cost. American Journal of Public Health 2004; in press.

15 Cade J, Upmeier H, Calvert C, Greenwood D. Costs of a healthy diet: analysis from the UK Women's Cohort Study. Public Health Nutrition 1999; 2: 505-12.

16 Stender S, Skovby F, Haraldsdottir J, Andresen GR, Michaelsen KF, Nielsen BS, et al. Cholesterol-lowering diets may increase the food costs for Danish children. A cross-sectional study of food costs for Danish children with and without familial hypercholesterolaemia. European Journal of Clinical Nutrition 1993; 47: 776-86.

17 Darmon N, Ferguson EL, Briend A. A cost constraint alone has adverse effects on food selection and nutrient density: an analysis of human diets by linear programming. Journal of Nutrition 2002; 132: 3764-71.

18 Raynor HA, Kilanowski CK, Esterlis I, Epstein LH. A costanalysis of adopting a healthful diet in a family-based obesity treatment program. Journal of the American Dietetic Association 2002; 102: 645-56.

19 Burney J, Haughton B. EFNEP: a nutrition education program that demonstrates cost-benefit. Journal of the American Dietetic Association 2002; 102: 39-45.

20 Mitchell DC, Shannon BM, McKenzie J, Smiciklas-Wright H, Miller BM, Tershakovec AM. Lower fat diets for children did not increase food costs. Journal of Nutrition Education 2000; 32: 100-3.

21 Meade $\mathrm{B}$, Rosen S. Income and diet differences greatly affect food spending around the globe. Food Review 1996; (Sept-Dec): 39-44.

22 Popkin BM, Haines PS. Factors affecting food selection: the role of economics. Journal of the American Dietetic Association 1981; 79: 419-25.

23 Cabanac M. Palatability vs. money: experimental study of a conflict of motivations. Appetite 1995; 25: 43-9.

24 Preziosi P, Galan P, Granveau C, Deheeger M, Papoz L, Hercberg S. Dietary intake of a representative sample of the population of Val-de-Marne. Revue d'Epidémiologie et de Santé Publique 1991; 39: 221-61.

25 Institut National de la Statistique et des Etudes Economiques. Indice des prix à la consommation. Bulletin Mensuel de Statistique 2000; 12: 90-2.

26 Drewnowski A, Rock CL, Henderson SA, Shore AB, Fischler C, Galan P, et al. Serum beta-carotene and vitamin C as biomarkers of vegetable and fruit intakes in a communitybased sample of French adults. American Journal of Clinical Nutrition 1997; 65: 1796-802.

27 Cubeau J, Pequignot G. The quantitative alimentary questionnaire technique used by the I.N.S.E.R.M. nutrition department [in French]. Revue d'Epidémiologie et de Santé Publique 1980; 28: 367-72.

28 Gibson SA. Associations between energy density and macronutrient composition in the diets of pre-school 
children: sugars vs. starch. International Journal of Obesity and Related Metabolic Disorders 2000; 24: 633-8.

29 Black AE. Physical activity levels from a meta-analysis of doubly labeled water studies for validating energy intake as measured by dietary assessment. Nutrition Reviews 1996; 54 : $170-4$.

30 Willett WC, ed. Nutritional Epidemiology, 2nd ed. New York: Oxford University Press, 1998.

31 Black AE. Critical evaluation of energy intake using the Goldberg cut-off for energy intake:basal metabolic rate. A practical guide to its calculation, use and limitations. International Journal of Obesity and Related Metabolic Disorders 2000; 24: 1119-30.

32 Grunwald GK, Seagle HM, Peters JC, Hill JO. Quantifying and separating the effects of macronutrient composition and non-macronutrients on energy density. British Journal of Nutrition 2001; 86: 265-76.

33 Drewnowski A. Fat and sugar: an economic analysis. Journal of Nutrition 2003; 133: 838S-40S.

34 Groupe de Travail Réuni par le Haut Comité de la Santé Publique. Consommation alimentaire et état nutritionnel de la population vivant en France. In: ENSP, ed. Pour une Politique Nutritionnelle de Santé Publique en France. Enjeux et Propositions. Rennes: Collection Avis et Rapports, 2000; 189-95.

35 Clément L, Destandaux S, Eneau D. Le budget des ménages en 1995. INSEE Résultats - Consommation Mode de Vie 1997; 90: $21-37$.

36 Smith AM, Baghurst KI. Public health implications of dietary differences between social status and occupational category groups. Journal of Epidemiology and Community Health 1992; 46: 409-16.

37 Lantz PM, House JS, Lepkowski JM, Williams DR, Mero RP, Chen J. Socioeconomic factors, health behaviors, and mortality: results from a nationally representative prospective study of US adults. Journal of the American Medical Association 1998; 279: 1703-8.

38 Brunner EJ, Marmot MG, Nanchahal K, Shipley MJ, Stansfeld SA, Juneja M, et al. Social inequality in coronary risk: central obesity and the metabolic syndrome. Evidence from the Whitehall II study. Diabetologia 1997; 40: 1341-9.

39 Molarius A, Seidell JC, Sans S, Tuomilehto J, Kuulasmaa K. Educational level, relative body weight, and changes in their association over 10 years: an international perspective from the WHO MONICA Project. American Journal of Public Health 2000; 90: 1260-8.

40 Evans JM, Newton RW, Ruta DA, MacDonald TM, Morris AD. Socio-economic status, obesity and prevalence of type 1 and type 2 diabetes mellitus. Diabetic Medicine 2000; 17: 478-80.

41 Tang M, Chen Y, Krewski D. Gender-related differences in the association between socioeconomic status and selfreported diabetes. International Journal of Epidemiology 2003; 32: 381-5.

42 Senauer E, Asp E, Kinsey J. Food economics: insightful and not so arcane. In: Senauer E, Asp E, Kinsey J, eds. Food Trends and the Changing Consumer, 3rd ed. St Paul, MN: Eagan Press, 1998; 133-53.

43 James WP, Nelson M, Ralph A, Leather S. Socioeconomic determinants of health. The contribution of nutrition to inequalities in health. British Medical Journal 1997; 314: $1545-9$.

44 Lennernas M, Fjellstrom C, Becker W, Giachetti I, Schmitt A,
Remaut de Winter AM, et al. Influences on food choice perceived to be important by nationally-representative samples of adults in the European Union. European Journal of Clinical Nutrition 1997; 51: S8-15.

45 Glanz K, Basil M, Maibach E, Goldberg J, Snyder D. Why Americans eat what they do: taste, nutrition, cost, convenience, and weight control concerns as influences on food consumption. Journal of the American Dietetic Association 1998; 98: 1118-26.

46 Kearney JM, McElhone S. Perceived barriers in trying to eat healthier - results of a pan-EU consumer attitudinal survey. British Journal of Nutrition 1999; 81: S133-7.

47 Lloyd HM, Paisley CM, Mela DJ. Barriers to the adoption of reduced-fat diets in a UK population. Journal of the American Dietetic Association 1995; 95: 316-22.

48 Dibsdall LA, Lambert N, Bobbin RF, Frewer LJ. Low-income consumers' attitudes and behaviour towards access, availability and motivation to eat fruit and vegetables. Public Health Nutrition 2003; 6: 159-68.

49 Hann CS, Rock CL, King I, Drewnowski A. Validation of the Healthy Eating Index with use of plasma biomarkers in a clinical sample of women. American Journal of Clinical Nutrition 2001; 74: 479-86.

50 Michaud C, Baudier F, Loundou A, Le Bihan G, Janvrin MP, Rotily M. Food habits, consumption, and knowledge of a low-income French population [in French]. Santé Publique 1998; 10: 333-47.

51 Hulshof KF, Lowik MR, Kok FJ, Wedel M, Brants HA, Hermus RJ, et al. Diet and other life-style factors in high and low socio-economic groups (Dutch Nutrition Surveillance System). European Journal of Clinical Nutrition 1991; 45 : $441-50$.

52 Krebs-Smith SM, Kantor LS. Choose a variety of fruits and vegetables daily: understanding the complexities. Journal of Nutrition 2001; 131: 487S-501S.

53 Roos G, Johansson L, Kasmel A, Klumbiené J, Prattala R. Disparities in vegetable and fruit consumption: European cases from the north to the south. Public Health Nutrition 2000; 4 : 35-43.

54 Lino $\mathrm{M}$ and staff at the Center for Nutrition Policy and Promotion. The Thrifty Food Plan, 1999: revisions of the market baskets. Family Economics and Nutrition Review 2001; 13: 50-63.

55 Lobstein T. Food policies: a threat to health? Proceedings of the Nutrition Society 2002; 61: 579-85.

56 Ludwig DS. The glycemic index: physiological mechanisms relating to obesity, diabetes and cardiovascular disease. Journal of the American Medical Association 2002; 287: 2414-23.

57 Patterson RE, Satia JA, Kristal AR, Neuhouser ML, Drewnowski A. Is there a consumer backlash against the diet and health message? Journal of the American Dietetic Association 2001; 101: 37-41.

58 Kennedy E, Ling M. Nutrition education for low-income groups - is there a role? In: Köhler BM, Feichtinger E, Barlösius E, Dowler E, eds. Poverty and Food in Welfare Societies. Berlin: Sigma edition, 1997; 349-62.

59 Frazao E. America's Eating Habits: Changes and Consequences. USDA/ERS Agriculture Information Bulletin No. 750. Washington, DC: US Department of Agriculture, 1999.

60 Young LR, Nestle M. The contribution of expanding portion sizes to the US obesity epidemic. American Journal of Public Health 2002; 92: 246-9. 